\title{
PENGARUH REBRANDING \\ TERHADAP CITRA BANK JAMBI PADA NASABAH
}

(Studi Pengaruh Perubahan Nama, Logo, Slogan dan Frontliner Terhadap Citra Bank Jambi pada

Nasabah Kantor Cabang Utama)

\author{
M. Ichsan Pratama \\ Universitas Muara Bungo
}

\begin{abstract}
ABSTRAK
Penelitian ini bertujuan untuk menguji seberapa besar pengaruh yang diberikan oleh perubahan nama, logo, slogan dan frontliner Bank Jambi terhadap citra perusahaan pada nasabah Bank Jambi Kantor Cabang Utama Kota Jambi. Pendekatan yang digunakan pada penelitian ini adalah kuantitatif dengan metode explanatory survey. Beberapa teori yang menjadi pegangan adalah teori psikologi kognitif, teori stimulus organism respons, dan teori manajemen citra organisasi. Populasi yang digunakan adalah nasabah Bank Jambi Cabang Utama yang berjumlah 3669 nasabah. Melalui teknik sampling secara acak sistematis, diperoleh sampel sebanyak 98 nasabah yang mewakili populasi tersebut. Data pada penelitian ini dikumpulkan melalui kuesioner, wawancara, studi kepustakaan, dan media internet. Kuesioner yang merupakan instrumen penelitian telah diuji validitas dan reliabilitas menggunakan teknik Pearson Product Moment. Selanjutnya data yang dihasilkan menggunakan kuesioner dianalisis menggunakan analisis jalur untuk melihat pengaruh dan signifikansi yang diberikan variabel-variabel eksogen terhadap variabel endogen. Berdasarkan penelitian yang telah dilakukan, hasilnya menunjukkan bahwa Frontliner dan Logo Bank Jambi mempengaruhi citra Bank Jambi pada nasabah secara siignifikan, dan Nama dan Slogan Bank Jambi mempengaruhi Citra Bank Jambi pada nasabah secara tidak signifikan. Secara keseluruhan, rebranding yang dilakukan Bank Jambi telah memberikan respons yang positif terhadap Citra Bank Jambi pada nasabah.
\end{abstract}

Kata-kata kunci: Rebranding, citra perusahaan, bank, Jambi

\author{
REBRANDING EFFECT ON THE IMAGE OF JAMBI BANK CUSTOMERS \\ (Study of Name, Logo, Slogan and Frontliner Changes Effects toward Jambi Bank's Image for \\ Main Branch Office Customer)
}

\begin{abstract}
This study aimed to test how much influence exerted by the change of name, logo, slogan and frontline Jambi Bank on the image of the company on a customer of Main Branch Office of Jambi Bank. The approach used in this research is quantitative with explanatory survey method. Some theories used in this study was cognitive psychology theory, the theory of stimulus organism response, and organizational image management theory. The population used is the Main Branch Jambi Bank's customers, 3669 customers in total. Through a systematic random sampling technique, sample id obtained of 98 customers who represent the population. The data in this study were collected through questionnaires, interviews, literature studies, and Internet. The questionnaire is a research instrument, which has been tested for validity and reliability by using Pearson Product Moment technique. Furthermore, the data generated using questionnaires were analyzed using path analysis to see the effect and significance of exogenous variables on endogenous variables. Research conducted, shows that the Frontliner and Jambi Bank Logo affect the image for the customer significantly, while the name and slogan of Jambi Bank influence clients is not significant. Overall, rebranding the Bank Jambi has a positive respond in term of the image of the Bank of Jambi for the customer.
\end{abstract}

Keywords: Rebranding, corporate image, bank, Jambi

Korespondensi: M. Ichsan Pratama, M.I.Kom. Universitas Muara Bungo, JL. Diponegoro No. 27, Muara Bungo, Jambi 37216, Indonesia. Email: m_ichsan_pratama@yahoo.com 


\section{PENDAHULUAN}

Perubahan lingkungan perusahaan dan semakin tingginya tuntutan dari nasabah memaksa Bank Jambi harus melakukan beberapa pembenahan. Bank Jambi yang merupakan bank milik pemerintah Provinsi Jambi telah melakukan beberapa perubahan pada akhir tahun 2007, mulai dari perubahan beberapa atribut bank seperti nama, logo, slogan, pelayanan frontliner yang ditingkatkan dan peningkatan fasilitas pendukung guna mencapai program service excellence. Langkah yang dilakukan Bank Jambi merupakan respons dari persaingan perbankan yang semakin kompetitif. Bank Jambi melalui perubahan-perubahan tersebut bertujuan untuk memperkenalkan identitas baru bank tersebut sebagai bank yang bukan hanya melayani kebutuhan pemerintah dan para Pegawai Negeri Sipil. Dengan kata lain Bank Jambi ingin memperbaiki citra bank yang terkesan konvensional dan tidak berkarakter serta tertinggal dari bank-bank pemerintah dan swasta. Fenomena yang dijelaskan di atas dijelaskan melalui teori manajemen citra organisasi yang dikembangkan oleh Joseph Eric Massey.

Massey (2003) memaparkan bahwa teori manajemen citra organisasi menjelaskan bagaimana menciptakan dan memelihara citra organisasi. Organisasi berkomunikasi secara strategis dengan para pemangku kepentingan untuk mendukung citra yang diinginkan dan mencegah yang tidak diinginkan. Perubahan pada lingkungan organisasi, dan perubahan pada organisasi itu sendiri menimbulkan tantangan pada pengelolaan citra. Tantangan tersebut terletak pada kemampuan organisasi memahami perubahan yang terjadi dan terus menyesuaikan citra organisasi untuk mengantisipasi dan/ atau merespons perubahan lingkungan.

Harrowitz (dalam Ardianto, 2010) mengemukakan bahwa citra terbentuk pada struktur kognisi manusia. Ardianto (2010: 98) menyimpulkan bahwa "citra merupakan serangkaian pengetahuan, pengalaman, perasaan dan penilaian yang diorganisasikan dalam sistem kognisi manusia". Henslowe (1999) mengatakan citra sebagai kesan yang tumbuh berdasarkan tingkat pengetahuan dan pemahaman tentang fakta suatu produk, seseorang atau perusahaan. Dalam konteks perusahaan, Riordan et al. (dalam Malhotra, 2008) mengkarakteristikkan citra sebagai persepsi individu tentang aksi, aktivitas, pencapaian suatu perusahaan.

Sehubungan dengan banyaknya pernyataan dari para ahli mengenai citra yang berhubungan dengan pengetahuan, pengalaman dan persepsi individu terhadap perusahaan, peneliti meminjam konsep sikap yang dikembangkan oleh Mar'at (1982). Pada konsep sikap tersebut, dijelaskan komponen sikap yang terdiri dari kognisi, afeksi, dan konasi. Fokus kepada komponen kognisi, terdapat dimensi pengetahuan, pengalaman dan persepsi manusia yang pada akhirnya membangun komponen kognisi tersebut. Pada teori terapan yang digunakan untuk penelitian ini, yaitu teori citra organisasi, juga menjelaskan bahwa citra menentukan tanggapan stakeholder terhadap organisasi secara kognitif (Massey, 2003).

Lanjut pada penjelasan tentang konsep rebranding perusahaan, Einwiller \& Will pada Riel (dalam Muzellec \& Lambkin, 2006) mengatakan:

"A good compromise is to see corporate
rebranding as "a systematically planned
and implemented process of creating
and maintaining a favourable image and
consequently a favourable reputation
for the company as a whole by sending
signals to all stakeholders and by
managing behaviour, communication,
and symbolism."

Kutipan tersebut menjelaskan bahwa rebranding perusahaan sebagaisuatuproses yang diimplementasikan dan direncanakan secara sistematis dalam menciptakan dan memelihara suatu citra yang baik dan sebagai konsekuen suatu reputasi yang baik bagi perusahaan secara keseluruhan dengan mengirimkan tanda kepada seluruh stakeholders dan dengan mengelola perilaku, komunikasi, dan penyimbolan. Artinya bahwa rebranding merupakan perubahan dan peningkatan kualitas komunikasi, perilaku dan simbolisasi yang dimiliki suatu perusahaan. Pada penelitian ini, yang menjadi fokus adalah perubahan pada aspek nama, logo, slogan dan frontliner Bank Jambi.

Aaker (1991) mendefinisikan brand adalah 
nama atau simbol yang berbeda yang bermaksud untuk mengidentifikasi kebaikan dan layanan penjual atau sekelompok penjual dan untuk membedakan kebaikan dan layanan tersebut dengan kompetitor yang lain. Brand bertujuan untuk mempermudah pelanggan atau konsumen dalam mengingat suatu produk/perusahaan. Menurut Duane E. Knap (2001) mengatakan merek adalah suatu jenis atau variasi dari sesuatu yang dibedakan oleh beberapa kharakteristik khusus.

Menurut Prayudi dan Juanita dalam Media Informasi Karyawan SCTV (2005), nama yang baik memiliki kriteria; (1) Nama terlihat khusus; (2) nama harus praktis; (3) Jelas secara grafis; (4) Sederhana dalam bentuk; (5) Satu pesan; (6) Sesuai dengan bisnis.

Logo menurut Franks Jefkins (1994) adalah presentasi, sosok atau tampilan visual yang senantiasa dikaitkan dengan perusahaan/ organisasi tertentu, dan digunakan sebagai suatu bentuk identifikasi dan bagian dari identifikasi dan bagian dari identitas perusahaan. Logo sebaiknya mudahan untuk dikenali, padanan warna sesuai, cocok dengan perusahaan, dan uniikan/berkarakter.

Slogan adalah motto atau frasa yang dipakai pada konteks politik, komersial, agama, dan lainnya, sebagai ekspresi sebuah ide atau tujuan yang mudah diingat. Slogan yang baik harus memiliki, kemudahan untuk dibaca, kemudahan untuk diingat, kesesuaian dengan bisnis perusahaan, kemudahan pesan untuk dipahami.

Frontliner sebagai mana artinya secara harfiah adalah 'garis depan', berarti merupakan petugas atau pegawai yang akan melakukan interaksi pertama ketika pelanggan mendatangi perusahaan. Ketentuan kerja frontliner telah diatur pada prosedur standar kerja. Pada Bank Jambi, standar tersebut meliputi penguasaan informasi tentang produk dan transaksi, kecepatan memproses transaksi, kerapian frontliner bank, kesopanan frontliner bank, dan keramahan frontliner.

Dengan berpedoman pada teori dan beberapa konsep yang telah dijelaskan di atas, penelitian ini bertujuan untuk mengukur: (1) Pengaruh nama terhadap corporate image Bank Jambi, (2) Pengaruh logo terhadap corporate image Bank Jambi, (3) Pengaruh slogan terhadap corporate image Bank Jambi, (4) Pengaruh frontliner terhadap citra Bank Jambi, dan (5) Pengaruh rebranding secara simultan terhadap citra Bank Jambi.

\section{METODE PENELITIAN}

Desain penelitian yang digunakan dalam penelitian ini adalah desain penelitian kuantitatif. Penelitian kuantitatif merupakan penelitian terhadap suatu masalah yang hasilnya dapat digeneralisasikan, berpikir secara deduktif. Untuk metode penelitian yang peneliti gunakan dalam penelitian ini adalah metode penelitian survei. Penelitian survei adalah metode penelitian denganmenggunakankuesioner sebagai intrumen pengumpulan datanya. Tujuan penggunaan metode ini adalah untuk memperoleh informasi tentang sejumlah responden yang dianggap mewakili populasi tertentu. (Krisyantono, 2006)

Creswell (2012) menjelaskan bahwa pada penelitian survei, peneliti mendeskripsikan kecenderungan-kecenderungan, perilakuperilaku, atau opini-opini dari suatu populasi dengan meneliti sampel populasi tersebut secara kuantitatif atau angka-angka. Menggunakan sampel itu kemudian peneliti melakukan generalisasi tentang populasi tersebut.

Jenis penelitian survei ini memfokuskan pada pengungkapan hubungan kausal antara variabel penyebab $(\mathrm{X})$ dengan variabel akibat (Y). Dalam penelitian ini variabel penyebab adalah rebranding Bank Jambi dan variabel akibat adalah Citra Perusahaan Bank Jambi pada nasabah.

Pada penelitian ini, instrumen penelitian yang digunakan dalam mengumpulkan data lapangan adalah kuesioner atau angket yang terdiri dari beberapa pernyataan yang mewakili masing-masing variabel dan sub variabel penelitian. Pada pembobotan jawaban yang diberikan responden, peneliti menggunakan Skala Likert, yaitu skala untuk mengukur sikap, pendapat, dan persepsi seseorang atau kelompok tentang suatu fenomena sosial yang terjadi (Riduwan \& Kuncoro, 2011: 20).

Variabel-variabel yang terdapat pada penelitian ini berjumlah 5 variabel, yakni 4 variabel bebas dan 1 variabel terikat. Tabel 1 menjabarkan operasionalisasi variabel-variabel beserta indikatornya. 
Tabel 1 Operasionalisasi Variabel-Variabel

\begin{tabular}{|c|c|c|}
\hline Variabel & Sub Variabel & Indikator \\
\hline \multirow[t]{4}{*}{ Rebranding (X) } & - Nama (X1) & $\begin{array}{l}\text { - Kemudahan diingat } \\
\text {. Kesesuaian dengan bisnis perusahaan } \\
\text {. Keunikan/berkarakter }\end{array}$ \\
\hline & - $\operatorname{Logo}(X 2)$ & $\begin{array}{l}\text { - Kemudahan untuk dikenali } \\
\text {. Padanan warna } \\
\text { · Kesesuaian dengan perusahaan } \\
\text { - Keuniikan/berkarakter }\end{array}$ \\
\hline & - Slogan (X3) & $\begin{array}{l}\text { - Kemudahan untuk dibaca } \\
\text { - Kemudahan untuk diingat } \\
\text {. Kesesuaian dengan bisnis perusahaan } \\
\text { - Kemudahan pesan untuk dipahami }\end{array}$ \\
\hline & - Frontliner (X4) & $\begin{array}{l}\text { Penguasaan informasi tentang produk } \\
\text { dan transaksi } \\
\text {. } \text { Kecepatan memproses transaksi } \\
\text { · Kerapian frontliner bank } \\
\text { - Kesopanan frontliner bank } \\
\text { - Keramahan frontliner bank }\end{array}$ \\
\hline Variabel Y & $\begin{array}{l}\text { Citra Bank Jambi } \\
\text { (Variabel Y) }\end{array}$ & $\begin{array}{l}\text { Pengetahuan nasabah tentang Bank } \\
\text { Jambi } \\
\text {. Pengalaman nasabah tentang Bank Jam- } \\
\text { bi } \\
\text {. Persepsi nasabah tentang Bank Jambi }\end{array}$ \\
\hline
\end{tabular}

Pada penelitian ini, populasi yang diambil oleh peneliti adalah populasi yang terbatas dan homogen yaitu nasabah Bank Jambi Cabang Utama.

Berdasarkan data jumlah nasabah Bank Jambi Cabang Utama tahun 2012 akhir, terdapat 3669 nasabah yang aktif. Pada penelitian ini, peneliti menggunakan teknik sampling yaitu Systematic random sampling. Karena jumlah populasi telah diketahui, maka peneliti menggunakan rumus Taro Yamane dalam menentukan jumlah sampel yang dibutuhkan, sehingga didapat sampel berjumlah 98 responden kemudian diambil secara acak sistematis.

Dalam mengumpulkan data yang dibutuhkan untuk penelitian ini, peneliti melakukan beberapa metode pengumpulan data yaitu kuesioner, wawancara, dan studi kepustakaan.

Dalam menguji validitas dan reliabilitas kuesioner penelitian, digunakan rumus Pearson 
Product Moment (PPM). Setelah item-item pertanyaan valid dan reliabel, kemudian kuesioner disebarkan kepada nasabah Bank Jambi. Data yang diperoleh dari lapangan menggunakan kuesioner, kemudian diolah melalui beberapa tahap, diantaranya tahap pemeriksan, tahap pemberian identitas (coding), tahap pembeberan/ tabulasi, transformasi data ordinal menjadi interval menggunakan MSI, dan penggunaan Analisis Jalur (Path Analysis)

\section{HASIL DAN PEMBAHASAN}

Bagian ini membahas mengenai uraian dan analisis data yang diperoleh dari data primer dan sekunder penelitian. Data tersebut merupakan data pokok dimana analisisnya ditunjang oleh data sekunder yang didapat dari hasil observasi di lapangan dan beberapa sumber pustaka untuk memperkuat dan memperdalam hasil analisis.

Sebelum menyebarkan instrumen penelitian kepada seluruh responden, peneliti terlebih dahulu memastikan bahwa instrumen penelitian yang telah dipersiapkan telah teruji validitas dan realibilitasnya. Oleh karena itu, peneliti menguji kuesioner kepada 20 orang responden, lalu kemudian melakukan uji validitas dan reliabilitas dengan sepenuhnya menggunakan bantuan Program Statistical Product and Service Solution (SPSS) versi 19. Dari total 40 item pernyataan, 7 penyataan untuk variabel $\mathrm{X} 1,7$ penyataan untuk variabel $\mathrm{X} 2,7$ penyataan untuk variabel $\mathrm{X} 3,7$ penyataan untuk variabel $\mathrm{X} 4$, dan 12 pernyataan untuk variabel Y. Terdapat 30 item pernyataan yang valid, dan 10 pernyataan yang tidak valid.

Hasil penelitian menggunakan analisis jalur menunjukkan hasil seperti berikut ini.

Tabel 2 Pengujian Secara Simultan

\begin{tabular}{|c|c|c|c|c|}
\hline Hipotesis Alternatif & F hitung & F tabel & Keputusan & Kesimpulan \\
\hline$X_{1}, X_{2}, X_{3}$ dan $X_{4}$ secara simultan berpengaruh terhadap Y & 36,329 & 2,47 & $\mathrm{H}_{0}$ ditolak & Signifikan \\
\hline
\end{tabular}

Pada Tabel 2 dapat kita ketahui bahwa hasil pengujian $\mathrm{F}$ hitung $(36,329)>\mathrm{F}$ Tabel $(2,47)$ hal ini berarti signifikan atau secara keseluruhan variabel Nama perusahaan (X1), logo perusahaan (X2), slogan perusahaan (X3) dan frontliner perusahaan (X4) memberikan pengaruh yang nyata terhadap Citra Perusahaan (Y).

Karena hasil pengujian secara keseluruhan memberikan hasil yang signifikan, maka untuk mengetahui variabel bebas mana yang secara parsial berpengaruh nyata terhadap $\mathrm{Y}$ dapat dilanjutkan dengan pengujian secara parsial.
Untuk menguji koefisien jalur secara parsial, terlebih dahulu ditentukan rumusan hipotesisnya sebagai berikut:

$H_{0}: P_{y x_{i}}=0$ Tidak terdapat pengaruh yang nyata variabel bebas yang ke-i $\left(\mathrm{X}_{\mathrm{i}}\right)$ terhadap $\mathrm{Y}$

$H_{1}: P_{y x_{i}} \neq 0$ Terdapat pengaruh yang nyata variabel bebas yang ke-i $\left(\mathrm{X}_{\mathrm{i}}\right)$ terhadap Y

Hasil perhitungan dapat kita lihat pada Tabel berikut ini:

Tabel 3 Pengujian Secara Parsial

\begin{tabular}{|c|c|c|c|c|c|c|}
\hline No & Hipotesis & $\begin{array}{c}\text { Koefisien } \\
\text { Jalur }\end{array}$ & t hitung & t tabel & Keputusan & Kesimpulan \\
\hline 1 & $P_{v x 1}=0$ & 0.123 & 1,290 & 1,99 & $\mathrm{H}_{0}$ diterima & Tidak signifikan \\
\hline 2 & $P_{v x 2}=0$ & 0.268 & 2,903 & 1,99 & $\mathrm{H}_{0}$ ditolak & Signifikan \\
\hline 3 & $P_{v x 3}=0$ & 0.136 & 1,587 & 1,99 & $\mathrm{H}_{0}$ diterima & Tidak signifikan \\
\hline 4 & $P_{v x 4}=0$ & 0.452 & 5,979 & 1,99 & $\mathrm{H}_{0}$ ditolak & Signifikan \\
\hline
\end{tabular}


Dari Tabel di atas dapat dilihat bahwa (1) Untuk variabel nama perusahaan $\left(\mathrm{X}_{1}\right)$ diperoleh nilai $\mathrm{t}$ hitung sebesar 1,290. Karena t hitung $(1,290)<\mathrm{t}$ tabel $(1,99)$ maka Ho diterima. Oleh karena itu, dapat disimpulkan bahwa nama perusahaan $\left(\mathrm{X}_{1}\right)$ secara parsial tidak memiliki pengaruh yang signifikan terhadap citra perusahaan (Y), (2) Untuk variabel logo perusahaan $\left(\mathrm{X}_{2}\right)$ diperoleh nilai $\mathrm{t}$ hitung sebesar 2,903. Karena thitung $(2,903)>t$ tabel $(1,99)$ maka Ho ditolak. Oleh karena itu, dapat disimpulkan bahwa logo perusahaan $\left(\mathrm{X}_{2}\right)$ secara parsial memiliki pengaruh yang signifikan terhadap citra perusahaan (Y), (3) Untuk variabel slogan perusahaan $\left(\mathrm{X}_{3}\right)$ diperoleh nilai t hitung sebesar 1,587. Karena t hitung $(1,587)$ $<\mathrm{t}$ tabel $(1,99)$ maka Ho diterima. Oleh karena itu, dapat disimpulkan bahwa slogan perusahaan $\left(\mathrm{X}_{3}\right)$ secara parsial tidak memiliki pengaruh yang signifikan terhadap citra perusahaan (Y), dan (4) Untuk variabel frontliner perusahaan $\left(\mathrm{X}_{4}\right)$ diperoleh nilai $\mathrm{t}$ hitung sebesar 5,979. Karena t hitung $(5,979)>\mathrm{t}$ tabel $(1,99)$ maka Ho ditolak. Oleh karena itu, dapat disimpulkan bahwa frontliner perusahaan $\left(\mathrm{X}_{4}\right)$ secara parsial memiliki pengaruh yang signifikan terhadap citra perusahaan $(\mathrm{Y})$.

Tidak hanya sampai disitu, hasil penelitian juga mengidentifikasi pengaruh yang diberikan variabel bebas melalui variabel bebas lainnya terhadap variabel terikat. Hasil yang diperoleh adalah (1) Dari tabel di atas dapat kita ketahui bahwa pengaruh langsung nama perusahaan terhadap citra perusahaan adalah sebesar $1,5 \%$, pengaruh tidak langsung melalui logo perusahaan sebesar $2,2 \%$, pengaruh tidak langsung melalui slogan perusahaan sebesar $1,0 \%$ dan pengaruh tidak langsung melalui frontliner perusahaan sebesar 1,88\%. Total pengaruh yang diberikan nama perusahaan terhadap citra perusahaan adalah sebesar $6,58 \%$, (2) Pengaruh langsung logo perusahaan terhadap citra perusahaan adalah sebesar $7,2 \%$, pengaruh tidak langsung melalui nama perusahaan sebesar $2,2 \%$, pengaruh tidak langsung melalui slogan perusahaan sebesar $1,9 \%$ dan pengaruh tidak langsung melalui frontliner perusahaan sebesar $5,30 \%$. Total pengaruh yang diberikan logo perusahaan terhadap citra perusahaan adalah sebesar 16,53\% (3) Dari tabel di atas dapat kita ketahui bahwa pengaruh langsung slogan perusahaan terhadap citra perusahaan adalah sebesar $1,9 \%$, pengaruh tidak langsung melalui nama perusahaan sebesar $1,0 \%$, pengaruh tidak langsung melalui logo perusahaan sebesar 1,9\% dan pengaruh tidak langsung melalui frontliner perusahaan sebesar $2,78 \%$. Total pengaruh yang diberikan slogan perusahaan terhadap citra perusahaan adalah sebesar 7,51\%, dan (4) Dari tabel di atas dapat kita ketahui bahwa pengaruh langsung frontliner perusahaan terhadap citra perusahaan adalah sebesar 20,4\%, pengaruh tidak langsung melalui nama perusahaan sebesar $1,9 \%$, pengaruh tidak langsung melalui logo perusahaan sebesar 5,3\% dan pengaruh tidak langsung melalui slogan perusahaan sebesar $2,78 \%$. Total pengaruh yang diberikan frontliner perusahaan terhadap citra perusahaan adalah sebesar 30,35\%.

Temuan penelitian menunjukan bahwa Nama Bank berpengaruh positif namun tidak signifikan terhadap citra Bank Jambi pada nasabah.

Zinkhan dkk. (2001) melalui jurnal mereka merumuskan model yang mengilustrasikan bahwa salah satu faktor yang dapat dikendalikan oleh perusahaan dalam membangun citra perusahaan adalah melalui identitas visual perusahaan, yang mana salah satunya adalah nama perusahaan. Mereka menjelaskan bahwa nama perusahaan harus mencerminkan jenis bisnis yang dijalani perusahaan tersebut.

Namun pada penelitian ini, hasil menunjukkan nama perusahaan tidak menjadi pertimbangan utama bagi nasabah untuk menilai citra Bank Jambi. Dibutuhkan asosiasi antara nama perusahaan dengan aspek lainnya untuk memberikan kontribusi yang lebih besar terhadap citra perusahaan. Penjelasan ini sejalan dengan pendapat Kapferer (1994) yang menyatakan bahwa konsumen membentuk citra melalui sintesis dari semua sinyal atau asosiasi yang dihasilkan perusahaan.

Untuk aspek logo Bank Jambi, menunjukkan kontribusi positif dan signifikan terhadap citra Bank Jambi. Artinya banyak nasabah yang menyukai logo yang digunakan Bank Jambi saat ini yaitu angka 9. Hasil penelitian tersebut diperkuat oleh pendapat Franks Jefkins (1994) yang menyebutkan logo sebagai presentasi, sosok atau tampilan visual yang senantiasa dikaitkan dengan perusahaan/ 
organisasi tertentu, dan digunakan sebagai suatu bentuk identifikasi dan bagian dari identifikasi dan bagian dari identitas perusahaan.

Hasil ini telah dibuktikan dan diperkuat oleh Kapferer (1994) yang menyatakan bahwa konsumen membentuk citra melalui sintesis dari semua sinyal atau asosiasi yang dihasilkan simbol visual (bisa logo dan slogan). Zinkhan dkk. (2001) melalui jurnal mereka merumuskan model yang mengilustrasikan bahwa salah satu faktor yang dapat dikendalikan oleh perusahaan dalam membangun citra perusahaan adalah melalui identitas visual perusahaan, yang mana salah satunya adalah logo perusahaan. Pernyataan Zinkhan dkk. tersebut telah terbuktikan melalui hasil penelitian ini.

Selanjutnya, hasil penelitian menunjukan bahwa Slogan Bank berpengaruh positif namun tidak signifikan terhadap citra Bank Jambi pada nasabah. Artinya nasabah sudah cukup mengetahui adanya penggunaan slogan oleh Bank Jambi.

Zinkhan dkk. (2001) melalui jurnal mereka merumuskan model yang mengilustrasikan bahwa salah satu faktor yang dapat dikendalikan oleh perusahaan dalam membangun citra perusahaan adalah melalui identitas visual perusahaan, yang mana salah satunya adalah slogan/tagline perusahaan. Pernyataan Zinkhan dkk. tersebut telah terbuktikan melalui hasil penelitian ini. Namun pada penelitian ini, slogan perusahaan tidak menjadi pertimbangan utama bagi nasabah untuk menilai citra Bank Jambi. Dibutuhkan asosiasi antara slogan perusahaan dengan aspek lainnya untuk memberikan kontribusi yang lebih besar terhadap citra perusahaan. Penjelasan ini sejalan dengan pendapat Kapferer (1994) yang menyatakan bahwa konsumen membentuk citra melalui sintesis dari semua sinyal atau asosiasi yang dihasilkan perusahaan.

Aspek yang terakhir, Frontliner Bank Jambi, memberikan kontribusi positif dan signifikan terhadap citra Bank Jambi. Di antara empat variabel penyebab, variabel frontliner memiliki hasil tertinggi. Artinya frontliner Bank Jambi memiliki peran yang sangat penting untuk berkontribusi terhadap citra Bank.

Hasil ini telah dibuktikan dan diperkuat oleh Zinkhan dkk. (2001) melalui jurnal mereka yang merumuskan model yang mengilustrasikan bahwa salah satu faktor yang dapat dikendalikan oleh perusahaan dalam membangun citra perusahaan adalah melalui perilaku pegawai garis depan (frontliner). Alasan mereka adalah pada beberapa situasi, perusahaan akan melakukan interaksi secara langsung dengan publik atau pelanggan.

Secara keseluruhan, temuan penelitian menunjukkan bahwa rebranding, yang terdiri dari beberapa perubahan, telah berkontribusi positif dan signifikan terhadap Citra Bank Jambi. Langkah yang dilakukan Bank Jambi dalam merespons keluhan dan kebutuhan nasabah dengan melakukan beberapa perubahan dianggap berhasil. Artinya nasabah dapat menerima dan menyambut positif perubahan pada Bank Jambi yang sedang terjadi.

Fakta hasil penelitian yang diperoleh telah diperkuat oleh pendapat Einwiller \& Will pada Riel (dalam Muzellec \& Lambkin, 2006) mengatakan corporate rebranding sebagai proses yang diimplementasikan dan direncakanan secara sistematis dalam menciptakan dan memelihara suatu citra yang baik dan sebagai konsekuen suatu reputasi yang baik bagi perusahaan secara keseluruhan dengan mengirimkan tanda kepada seluruh stakeholders dan dengan mengelola perilaku, komunikasi, dan penyimbolan.

Mengacu kepada teori yang diaplikasikan pada penelitian ini, yaitu teori manajemen citra organisasi yang dikembangkan oleh Massey (2003), terbukti bahwa penjelasan teori mengenai tujuan mengelola citra yang terdiri dari menciptakan citra baru, memelihara citra yang sudah ada, dan memperbaiki citra yang bermasalah telah menghasilkan hasil yang positif pada fenomena rebranding Bank Jambi. Stigma negatif masyarakat mengenai Bank Jambi dapat berubah menjadi positif dilihat dari hasil penelitian ini. Bank Jambi, berdasarkan hasil penelitian telah mampu merespons dan mengantisipasi perubahan lingkungan dengan melakukan rebranding yang menyebabkan beberapa perubahan pada nama, logo, slogan, dan frontliner perusahaan. Teori Manajemen Citra Organisasi (Massey, 2003) mengatakan bahwa apabila citra dikelola dengan baik akan memungkinkan untuk mengkoordinasikan kegiatan organisasi yang konsisten dengan harapan para stakeholder. 


\section{SIMPULAN}

Secara keseluruhan Bank Jambi telah melakukan rebranding dengan baik, terbukti dari hasil penelitian ini yang menunjukan hasil signifikan. Dari beberapa upaya yang telah dilakukan Bank Jambi, perubahan di aspek frontliner mendapat apresiasi yang paling positif dan signifikan dari para nasabah Bank Jambi. Artinya, mereka merasakan perubahan yang semakin baik dari aspek frontliner bank. Selain itu, logo Bank Jambi juga dinilai berkarakter dan cocok untuk Bank Jambi. Para nasabah juga mengapresiasikan perubahan logo tersebut dengan respons yang positif. Pada aspek nama bank, perubahan nama dari Bank Pembangunan Daerah Jambi (BPD Jambi) menjadi Bank Jambi, mampu memberikan respons yang positif meskipun tidak signifikan. Slogan Bank Jambi "Mitra Usaha Seiring Sejalan" menjadi aspek terakhir, atau yang terendah dalam memberikan kontribusi terhadap pembentukan citra bank, namun aspek ini juga cukup memberikan respons yang positif dari nasabah Bank Jambi.

Sebagai saran, perlu dilakukan asosiasi nama melibatkan periklanan dan kegiatan sponsorship untuk semakin memperkuat dan mempertegas nama baru tersebut, sehingga seluruh nasabah akan terbiasa dengan menggunakan/ menyebutkan nama 'Bank Jambi'. Perlu dilakukan publikasi slogan secara intensif. Bank Jambi juga harus menjaga konsistensi performa frontliner saat berinteraksi dengan nasabah.

\section{DAFTAR PUSTAKA}

Massey, J. E. (2003). A Theory of organizational image management: antecedents, processes \& outcomes. Orlando: International Academy of Business Disciplines Annual Conference.
Ardianto, E. (2010). Metode penelitian untuk public relations kuantitatif dan kualitatif. Bandung: Simbiosa Rekatama Media.

Henslowe, P. (1999). Public relations: a practical guide to the basics. London: Kogan Page Limited.

Malhotra, A. (2008). A study of the concept of image as expressed through corporate landscapes. Virginia: Virginia Polytechnic Institute and State University.

Mar'at. (1982). Sikap manusia perubahan serta pengukurannya. Jakarta: Ghalia Indonesia.

Muzellec, L. \& Lambkin, M. (2006). “Corporate rebranding: destroying, transferring or creating brand equity?". European Jurnal of Marketing Vol. 40 No. 7/8, pp. 803824.

Aaker, D. A. (1991). Managing brand equity: capitalizing on the value of a brand name, New York: The Free Press.

Knapp, D. E. (2001). The brand mindset. Penerjemah: Sisnu hadi \& Andi. Yogyakarta.

Prayudi \& Juanita, J. (2005). Strategic corporate communication dalam proses repositioning dan rebranding. Jurnal Ilmu Komunikasi. Yogyakarta Vol. 2, pp. 159176.

Jefkins, F. (1994). Public relations untuk bisnis. Penerjemah: Frans Kowa. Jakarta: Pustaka Binaman Pressindo. . (2013). Slogan. Diakses dari http:// id.wikipedia.org/wiki/Slogan, pada 29/01/2013.

Krisyantono, R. (2006). Teknik praktis riset komunikasi. Jakarta: Kencana Prenada Media Group.

Creswell, J. W. (2012). Research design: pendekatan kualitatif, kuantitatif, dan mixed. Penerjemah: Achmad Fawaid. Yogyakarta: Pustaka Pelajar. 